\title{
Women's Organizations in Iowa: Selected Holdings in Major Iowa Repositories
}

THE FOREGOING ARTICLES convey some of the diversity among women's organizations in Iowa. But they only begin to do so. The women's organizations established in Iowa run the entire gamut from neighborhood social clubs and sewing circles to groups that banded together for educational, political, religious, economic, or professional reasons. Joining a club allowed a woman to serve her community while achieving some social status or recognition within her community or state. Perhaps of greater importance to some was the opportunity to extend their education or to serve as mentors to younger members of the club. The strong grass-roots organizing by local chapters, formed as part of a larger national organization, often placed Iowa women in leadership roles while linking them to the outside world.

For over one hundred years, major research institutions in Iowa have preserved women's records. The State Historical Society of Iowa in Iowa City made a concerted effort, beginning at the turn of the century, to document women's activities in Iowa. And Dr. William J. Petersen, partially to support a fundraising drive in 1957, garnered local club records from around

For compiling the entries for this listing, thanks are due to Tanya ZanishBelcher at the Archives of Women in Science and Engineering, Parks Library, Iowa State University; Karen Mason and Robert Jett at the Iowa Women's Archives, University of Iowa Libraries; and Becki Peterson at the State Historical Society of Iowa, Des Moines. Most of all, Mary Bennett deserves praise and gratitude for proposing the idea for this listing, compiling the list of items from Special Collections at the State Historical Society of Iowa in Iowa City, and preparing the introduction.

THE ANNALS OF IOWA 56 (Winter/Spring 1997). CThe State Historical Society of lowa, 1997. 
the state for a proposed Women's Heritage Room (which never materialized). In the 1970s the women's movement and the emergence of women's studies stimulated the collection of materials relating to women. In the mid-1970s Andrea Hinding (in association with the University of Minnesota) led a systematic effort to identify primary source materials relating to women that might be hidden in archives. The resulting 1979 publication, Women's History Sources, served as a landmark study but also pointed to the need for further collecting. In 1992 the University of Iowa established the Iowa Women's Archives, the first serious collecting initiative in Iowa devoted primarily to material about women. Working cooperatively, Iowans are helping to create a comprehensive source of information by and about women from every station of life - of different ages, races, occupations, or religions and from both rural and urban areas.

Scholars can trace Iowa women's activities by using the archival record to reveal how literate women transmitted ideas about American culture and government. Typically, organizational records contain constitutions and bylaws (which spell out the mission and purpose of the club), minutes of meetings, reports, correspondence, financial records, scrapbooks, newsletters, membership lists, yearbooks, and directories. The material found in scrapbooks can vary considerably, ranging from programs, news clippings, and photos to reports on project activities or small mementoes from club events. The depth of coverage for any one club may be limited, but comparative analysis of the records of several smaller groups may yield significant information about women's involvement in the club movement.

Documentary materials relating to women's organizations are often embedded within larger collections of personal papers. This list does not attempt to include every women's organization documented in the archives, but focuses on those clubs that deposited official records. Additionally, many clubs had both male and female members and therefore do not fit the narrower criteria defined for this list. This would be especially true in the case of church records but also for groups such as the United Nations Association, the Republican State Central Committee of Iowa, the Iowa Commission on the Status of Women, and various labor unions. 
Vast numbers of Iowa women were actively engaged in bettering their lives and their communities. Their clubs did not focus exclusively on civic housekeeping; they sought involvement in local, national, and international issues affecting all citizens. The extensive holdings described here reinforce the need to further investigate and interpret the lives of Iowa women who frequently sought intellectual stimulation and community participation in the public arena.

\section{Special Collections Department, Parks Library, Iowa State University}

Iowa Farm Bureau, Women's Committee. Records, 1941-1978. $1.7 \mathrm{ft}$. Conference materials, handbooks for county chairpersons, reference books, workbooks for members, and booklets for Farm Bureau Women's Committees in other countries.

Iowa Master Farm Homemaker's Guild. Records, 1928-1992. $4.1 \mathrm{ft}$. Conference correspondence, minutes, historian's book, and secretary's books.

Iowa Organization of Women for Agriculture (I.O.W.A.). Records, 1984-1986. 2 in. Conference programs and newsletters.

League of Women Voters of Iowa. Records, 1961-1970. 1.3 ft. Minutes of state board meetings, state council meetings, and conventions; position papers; state board reports; and reports on ongoing League projects.

\section{Archives of Women in Science and Engineering, Special Collections Department, Parks Library, Iowa State University}

Association for Women Geoscientists. Records, 1975- . $16 \mathrm{ft}$. Minutes and newsletters pertaining to the Iowa City chapter of this national organization.

Curtiss-Wright Engineering Cadettes Program (Iowa State University). Records, 1941-1943. 2 in. Quizzes and course schedules for this World War Il engineering program.

Program for Women in Science and Engineering, Iowa State University. Records, 1986- . $7.5 \mathrm{ft}$. Career conference materials, internships, and minutes concerning the program, designed to mentor women students at Iowa State University and other Iowa schools.

Society of Women Engineers, Iowa State University Chapter. Records, 1975- . $1.5 \mathrm{ft}$. Newsletters, minutes, resumé books, and photographs. 


\section{Iowa Women's Archives, University of Iowa Libraries}

American Business Women's Association, Grant Wood Chapter. Iowa City. Records, 1971-1994. 2.75 ft. Subject files, scrapbooks.

Athens History Circle. Iowa City. Records, 1900-1995. 1 ft. History, membership lists, programs, scrapbooks, speeches.

Best Ever Club. Percival. Records, 1929-1994. 9 in. Women's study club founded in 1922. Scrapbooks, minutes.

Burlington Women's Clubs. Time capsule, 1896, 1946. 5 in. Summaries of the activities of the women's organizations in Burlington, Iowa, placed in a time capsule in 1896 and 1946.

Cary Club of Marion. Records, 1883-1980. 2 ft. Reading club. Minutes, rosters, correspondence.

Church Women United in Iowa. Records, 1933-1983. 8 feet. Ecumenical organization. Correspondence, reports, audits, minutes.

Clionian Club. Davenport. Records, 1874-1990s. 1.25 feet. Study club founded in 1874 . Scrapbooks, yearbooks, record books, programs, photograph.

Daughters of Ceres. Records, 1898-1988. 5 in. Walnut and Webster chapter records of this social and benevolent club comprising farm women. Minutes, correspondence, photographs.

ERA Iowa 1992. Records, 1990-1992. Organization to promote the passage of the Equal Rights Amendment in Iowa. Correspondence, subject files, newspaper clippings, publicity materials.

Emerson Study Club. History, 1992. History of this study club, 1892-1992.

Entre Nous. Iowa City. Records, 1914-1992. $1.1 \mathrm{ft}$. Women's drama study club founded in 1914 in lowa City. Annual programs, minutes, photographs.

Friendly Neighbors Club. Percival. Records, 1935-1995. 7 in. Social club organized in April 1935 by farm women. Minutes, scrapbooks.

Ingleside Club. Mount Vernon. Records, 1993-1995. 1.25 in. Program on feminism discussed by this book club.

Iowa Citizens' League for Nursing. Records, 1970-1973. 6 in. Organization to promote standardized education and continuing education for nurses. Minutes, correspondence, newsletters.

Iowa E.R.A. Coalition. Records, 1979-1980. $4 \mathrm{ft}$. Organization to promote passage of an Equal Rights Amendmeht to the Iowa and U.S. Constitutions. Subject files, correspondence, minutes.

Iowa National Organization for Women. Records, 1976-1989. $5 \mathrm{ft}$. Organization committed to equal rights for women. Subject files, newsletters, correspondence.

Iowa Nurses Association. Records, 1904-1989. 83 feet. Organization founded in 1904 to promote standardized nursing education and to improve the status of nurses. Correspondence, minutes, newsletters, administrative and conference files. 
Iowa Nurses Association. Fifth District. Records, 1922-1994. $2 \mathrm{ft}$. Local chapter of Iowa Nurses Association. Minutes, newsletters, photographs.

Iowa Press Women. Records, 1933-1973. $2 \mathrm{ft}$. Local affiliate of the National Federation of Press Women. Newspaper clippings, correspondence, reports. Iowa Suffrage Memorial Commission. Records, 1910-1941. 2 in. Commemorated the efforts of pioneer suffragists and the enfranchisement of women. Correspondence, reports, speeches, bulletins, and pamphlets.

Iowa Women against the Equal Rights Amendment. Records, 1976-1980. 2 in. Grass-roots organization opposed to Iowa's ratification of the ERA to the lowa and U.S. Constitutions. Pamphlets, newspaper clippings, audiovisual material. Iowa Women in Natural Resources. Records, 1979-1996. $1.5 \mathrm{ft}$. plus audiovisual materials. Organization to promote communication among persons in natural resources. Treasurer's files, newsletters, board minutes, membership lists, audiovisual material.

Iowa Women's Political Caucus. Records, 1972-1980. $5 \mathrm{ft}$. Organization that promotes the advancement of women in politics. Correspondence, subject files, minutes.

Johnson County E.R.A. Coalition. Iowa City. Records, 1984-1993. 2.5 in. plus audiovisual material. Organized in 1992 to promote the passage of the Equal Rights Amendment to the Iowa Constitution. Correspondence, minutes, reports, newspaper clippings, videocassettes.

Know Your Neighbor Club. Des Moines. Records, 1926-1997. 6 in. Local women's club. History, minutes, membership lists, ledger, photographs.

League of Women Voters of Iowa. Records, 1920-1991. $77.5 \mathrm{ft}$. Nonpartisan organization that informs voters and works for better government. Annual reports, minutes, correspondence.

League of Women Voters of Johnson County. Records, 1920- . $12 \mathrm{ft}$. Correspondence, minutes, newsletters.

League of Women Voters of Metropolitan Des Moines. Records, 1936-1995. $8.25 \mathrm{ft}$. plus audiovisual material. Minutes, reports, printed materials.

League of Women Voters of Mt. Vernon-Lisbon. Records, 1955-1995. $1.75 \mathrm{ft}$. plus audiovisual material. Correspondence, minutes, newsletters.

Lowell Club. Boone. Centennial commemorative history scrapbook, 1987. 1 vol. (2 in.). Study club founded in 1887.

Marion Federation of Women's Clubs. Records, 1905-1957. Minutes, newspaper clippings, treasurer's records.

Monday Club. Decorah. Records, 1981. History of this local women's club. Biographical sketches, photographs.

Muscatine Garden Club. Records, 1929-1996. 8.25 in. Yearbooks.

Muscatine Herb Pals. Records, 1947-1996. 1 ft. Local garden club. Scrapbooks, yearbooks, minutes, newsletters, photographs.

National Association of Women in Construction. Des Moines Chapter. Scrapbook, 1961-1964. 1 vol. ( 1 in.). Chartered in 1963 to provide a forum for women 
who are employed or own businesses in the construction industry to "exchange ideas and enjoy stimulating programs."

National Organization for Women. Ames Chapter. Records, 1973-1986. 7 in. Administrative records, newsletters, ERA campaign material.

National Organization for Women. Des Moines Chapter. Records, 1971-1987. 3 in. Correspondence, newsletters, printed materials.

National Organization for Women. Dubuque. Records, 1973-1995. $1.25 \mathrm{ft}$. Correspondence, newspaper clippings, newsletters, subject files, photographs, audiovisual material.

National Organization for Women. Johnson County-Iowa City Chapter. Records, 1977-1985. $6 \mathrm{ft}$. Correspondence, minutes, topical files.

New Art Club of Marion. Records, 1939-1974.3 in. Arts and crafts club formed in 1935. Minutes, newspaper clippings, photographs.

North Madison Happy Pals 4-H Club. Scrapbooks, 1952-1972. 6 vols. (1.25 ft.). 4-H chapter organized in Mahaska County in 1952.

Percival Needlecrafters. Scrapbooks, 1976-1992. 5 in. Needlework club.

Polk County Women Attorneys. Records, 1986-1995. 9 in. Organization to promote the professional growth of women in the law through educational and job placement programs and other activities. Correspondence, bylaws, minutes, subject files.

Professional Women's League. Des Moines. Records, 1903-1992. 2.2 ft. Organization of professional women founded in 1900. Minutes, yearbooks, programs, scrapbooks, photographs.

Proteus Club. Des Moines. Records, 1897-1993. $2.4 \mathrm{ft}$. Women's study club organized in 1896 by college graduates. Correspondence, programs, photographs.

Recital Club. Garner. Records, 1901-1994. $2.8 \mathrm{ft}$. Organized in 1901 to promote the arts and community service. Correspondence, minutes, photographs.

Shakespeare Club of Marion. Records, 1909-1955. $2 \mathrm{ft}$. History and literature club formed in 1909. Minutes, programs, scrapbooks.

Thimble Club. Riceville. Records, 1912-1957. 5 in. Women's club. Programs, photographs.

United Sisters of Black Hawk County. Records, 1986-1996. 1 ft. AfricanAmerican women's group of the YWCA of Black Hawk County. Photo albums, minutes, correspondence, announcements, newspaper clippings, mailing lists. Women's International League for Peace and Freedom. Des Moines Branch. Records, 1962-1996. $1.75 \mathrm{ft}$. Minutes, flyers, newspaper clippings, pamphlets, scrapbook.

Women's Resource and Action Center, University of Iowa. Iowa City. Records, 1960-1989. $4.5 \mathrm{ft}$. Women's center established in 1970 to serve University of Iowa women and the Iowa City community. Resource files, correspondence, reports, photographs.

YWCA of Greater Des Moines. Records, 1895-1995. 10.75 linear feet. Local chapter affiliated with the National YWCA in 1896. Records, minutes, newspaper clippings, scrapbooks, photographs. 


\section{State Historical Society of Iowa Manuscript Collection, Des Moines Center}

Aloha Club. Des Moines. Records, 1899-1963. 2 ft. Study club.

Altrusa Club. Des Moines. Records, 1920-1987. $3 \mathrm{ft}$. Social and community service club.

American Association of University Women. Indianola. Scrapbook, 1938-1940.

American Legion Auxiliary, Post 620. West Des Moines. Records, 1930s-1950s. $1 \mathrm{ft}$.

Athena Club. Des Moines. Yearbooks and secretary's books, [1930-1973]. 6 in. Study club.

Catholic Daughters of America, Iowa Court 302. Des Moines. Yearbooks and programs, 1940s-1970s. $1 \mathrm{ft}$.

Church Women United. Records, 1940's-1960's. $4 \mathrm{ft}$.

Daughters of Union Veterans (various Iowa tents). Circulars and scrapbooks. 7 scrapbooks and miscellaneous records.

Des Moines Federation of Women's Clubs. Records, 1920s-1960s. $8 \mathrm{ft}$.

Dubuque Conversational Club. Records, 1868-1916. 6 in.

Entre Nous Club. Des Moines. Records, 1930s-1990s. 1 ft. Study club.

51st Iowa Mothers Prayer Circle. Organization for mothers of soldiers in the 51st Iowa Infantry, Spanish-American War. Two volumes of secretary's records, 1899-1900.

Iowa Association of Colored Women's Clubs (also known as Iowa State Federation of Afro-American Women's Clubs and lowa Federation of Colored Women's Clubs). Records, 1900s-1970s. $1 \mathrm{ft}$.

Iowa Farm Bureau Women. Polk County. Records, 1970s-1980s. 6 in.

Iowa Women's Suffrage Collection. Contains various records of the Iowa Women's Suffrage Society, Iowa Equal Suffrage Association, Iowa Suffrage Memorial Commission, Iowa League of Women Voters, and Des Moines Political Equity Club. 1866-1951. $9.5 \mathrm{ft}$.

Junior Federation of Women's Clubs (mostly Des Moines, random records of other Iowa locations). Records, 1920s-1950s. $1 \mathrm{ft}$.

Monday Club. Des Moines. Records, 1896-1935, 1948-1985. $1.5 \mathrm{ft}$. Study club.

North Side Club. Des Moines. Minutes, yearbooks, treasurer's books, 18941981. $1 \mathrm{ft}$.

Pioneer Educators Organization, Chapter DD. Boone. Yearbooks, 1906-1948.

Pioneer Educators Organization, Chapter Q. Des Moines. Yearbooks, 19121964.

Polk County Women's Republican Association. Minutes and correspondence, 1938-1959. 6 in. 
Portia Club. Des Moines. Scrapbook, 1909-1989. Study and elocution club. Poweshiek Township Women's Club. Jasper County. Yearbooks, 1913-1973. Sammie's Mothers. Mahaska County. 2 scrapbooks, 1917-1919. Organization for mothers of World War I soldiers.

Service Star Legion of Iowa. Records of Jowa Division, 1920s-1970s. $1 \mathrm{ft}$., plus 6 volumes of records maintained by 23 local chapters. Women's organization for relatives of World War I soldiers.

Social Literary Circle of East Des Moines. Minutes, 1883-1895. 1 vol.

Sunset Study Club. Des Moines. Records, 1919-1993. $1 \mathrm{ft}$.

Tourist Club. Des Moines. Correspondence, yearbooks, secretary's books, 18921959. $1.5 \mathrm{ft}$.

United Service Women of America. Records from various Iowa county organizations, 1940s-1960s. $9 \mathrm{ft}$.

Widows of W.W. I, Inc., Iowa Chapter No. 2. Des Moines. Records, 1961-1979. 6 in.

Woman's Christian Temperance Union. Dexter. Minutes, 1880-1882. 1 vol.

Woman's Christian Temperance Union of Iowa. Records, 1938-1948. 8 folders.

Women's Advertising Club of Des Moines. Yearbooks, 1961-62, 1962-63.

Women's Auxiliary Army Corps. Scrapbooks, newspaper clippings, publications. $4 \mathrm{ft}$.

Women's Catholic Order of Foresters, St. John's Court 994. Maloy. Rostèr and endowment certificate register, 1913-1917. 2 vols.

Women's Relief Corps. Records from various Iowa corps. $6 \mathrm{ft}$. Auxiliary to Grand Army of the Republic. There are also W.R.C. records in the Grand Army of the Republic record group of the State Archives of Iowa.

Women's Relief Corps, Crocker Corps \#27. Des Moines. Records, 1948-1974. 4 folders.

Women's Relief Corps, Kinsman Corps \#24. Des Moines. Records, 1888-1947. $2 \mathrm{ft}$.

\section{State Historical Society of Iowa Manuscript Collection, Iowa City Center}

ADA Reading Circle. Maynard. Community Heritage Scrapbook, 1959. 1 vol. AMVETS Auxiliary, Dept. of Iowa. Records, 1942-1983. $16 \mathrm{ft}$. Service club for wives, mothers, daughters, and sisters of veterans of World War II, Korean War, and Vietnamese Conflict. Scrapbooks, correspondence, secretary's and treasurer's records for state, district, and local units.

American Association of University Women (AAUW), Iowa Division. Records, 1923-1983. $26 \mathrm{ft}$. State and local records include reports, minutes, correspon- 
dence, newsletters, club histories, scrapbooks, directories, convention proceedings, photos.

Amistad Circle. Iowa City. Records, 1935-1969. 1/2 ft. Social club also called El Circulo de la Amistad. Minutes, treasurer's reports, membership lists, bylaws, and correspondence.

Art Circle. Iowa City. Records, 1901-1980. $1 \mathrm{ft}$. Secretary's books, account book, scrapbook, photos, constitution and bylaws, correspondence.

Augusta Methodist Episcopal Church, Ladies Aid Society. Records, 1915-1925. 1 vol.

Auxiliary of Johnson County Barracks \#1139 of World War I Veterans. Scrapbooks, 1957-1962. 2 vols.

Book and Basket Club. Iowa City. Records, 1939-1961. 2 vols. Minutes of meetings, constitution, and dues records for neighborhood club that discussed short stories or current events while sewing or mending.

Burlington Study Club. Scrapbook, 1941-1960. 1 vol.

Cedar Rapids First Lutheran Church, Women's Society. Records, 1868-1963. $3 \mathrm{ft}$.

Charles City Equality Club. Secretary's books, 1891-1897. 2 vols.

Class in English Literature. Vinton. Records, 1880-1881. 1 folder. Constitution, minutes of meetings, and list of members. Also relates to Vinton Reading Association and interest in setting up a library.

Clinton Presbyterian Church, Women's Home Missionary Society. Minutes, 1891-1900. 1 vol.

Clio Club. Carroll. Histories of club, 1909 and 1938. 1 folder.

Columbia Circle. Clarence. Records, 1885-1910. 1 ft. Secretary's books, include minutes and attendance records.

Correctionville Federated Woman's Club. Scrapbook, 1955. 1 vol.

Council of Church Women. Iowa City. Scrapbook, 1953-1959. 1 vol.

Daughters of American Colonists. Iowa Society. Records, 1922-1962. 3 vols. plus 2 folders. Minutes, membership reports, and scrapbooks with correspondence, annual reports, news clippings, and photographs.

Daughters of the American Revolution. Iowa Society. Records, 1898-1994. 25.5 $\mathrm{ft}$. State and chapter records, include minutes, scrapbooks, yearbooks and directories, newsletters, historical project reports, financial records, chaplain's records, and necrology rolls.

Daughters of Union Veterans, Auntie Maria Hammer Tent \#26. Iowa City. Records, 1923-1966. $1 \mathrm{ft}$. Minutes, reports, scrapbooks, programs, and history. Also state, district, and national materials.

Davenport Diocesan Council of Catholic Women (District 3). Records, 19521979. $1 / 2 \mathrm{ft}$. Minutes, bulletins and newsletters, reports, and membership directories.

Davenport Music Club. Photographs and brief history from newspapers, ca. 1958. 1 folder. 
Des Moines Women's Club. Bulletins, 1887-1996. 11/2 ft. (Additional correspondence and materials in Alice Carey Weitz Papers).

East Lucas Woman's Club. Iowa City. Records, 1920-1970. 1/2 ft. Minutes, constitution and bylaws, membership list, correspondence, and 70th anniversary program.

Elder Daughters of the State University of Iowa. Iowa City. Minutes and treasurer's statements, 1900-1934. 2 folders.

Entre Nous Club. Iowa City. Records, 1915-1954. 1/2 ft. Organization devoted to dramatic readings and plays and full-scale productions of plays. Records include constitution and bylaws, programs, and annual yearbooks.

Equality Club. Eagle Grove. Scrapbook, 1943-1944. 1 vol. Includes programs, club history, photographs, and clippings.

Etude Club. Davenport. Club history, ca. 1961. 3 pp.

Fort Dodge Junior Woman's Club. Project scrapbook, 1954. 1 vol.

Fremont Baptist Church, Ladies Aid Society. Records, 1915-1921. 10 folders.

Half Hour Club. Columbus Junction. Secretary's books, 1896-1956. 8 vols.

Henry County Federated Women's Club. Secretary's book, 1928-1964 and record book, 1952-1970. 2 vols.

Highland Social Club. Highland Township, Washington County. Records, 1934-1981. 8 vols. Formerly called Highland Sewing Circle. Minutes, membership lists, treasurer's reports, programs, constitution, and history written for 50 th anniversary.

Iowa City Book Club. Records, 1888-1898. 2 folders. Secretary-treasurer's books, include accounts and minutes.

Iowa City Child Study Club. Records, 1917-1961. 1/2 ft. Organization for women interested in the study of children's problems. Minutes and treasurer's books.

Iowa City Country Club. Records, 1934-1942. 1 vol. Includes minutes, membership lists, financial records, and news clippings of the Golf Association for Women of the Iowa City Country Club.

Iowa City First Presbyterian Church, Women's Club. Treasurer's book, 19231938. 1 vol.

Iowa City Presbyterial Society. Records, 1936-1959. 1 ft. Scrapbook, president's records and correspondence, minutes, financial records, membership lists.

Iowa City Woman's Club. Records, 1927-1972. 3 ft. Scrapbooks, secretary's books, treasurer's books, press book, programs, and project book.

Iowa Commission on the Status of Women. Writing competition for National Women's History Week, 1985-1988. $1 \mathrm{ft}$.

Iowa Council of Republican Women. Scrapbooks, 1937-1982. $4 \mathrm{ft}$.

Iowa Dietetic Association. Records, ca. 1930-1995. 31/2 ft.

Iowa Farm Bureau Women. Histories of county organizations, 1965-1976. $2 \mathrm{ft}$. 
Iowa Federation of Business and Professional Women's Clubs. Records, 19191994. $27 \mathrm{ft}$. Includes state, district, and local club records for over 75 local chapters. Minutes, treasurer's reports, newsletters, scrapbooks, yearbooks, annual reports, histories.

Iowa Federation of Women's Clubs. Records, 1893-1984. $1 \mathrm{ft}$. Includes survey forms sent to local clubs asking for lists of projects and participation figures, 1965.

Iowa Mothers Association. Records, 1960-1989. 2 ft. Organization sponsors the Iowa Mother of the Year Award.

Iowa Presbyterial Society. Records, 1930-1959. 1 ft. Treasurer's records, quarterly reports, minutes, and correspondence relating to several Iowa locations.

Iowa Press and Author's Club. Des Moines. Records, 1896-1919. 1/2 ft. Called the Des Moines Women's Press Club until 1909; Women's Press and Authors Club in 1910. Includes history of club, correspondence, and news clippings relating to well-known authors.

Iowa Yearly Meeting, Society of Friends. Women's Missionary Union Handbook, 1941-1942. $16 \mathrm{pp}$. (Also various records from women's meetings across the state.)

Johnson County Democratic Women's Club. Records, 1962-1976. 6 folders. Newsletters, correspondence, membership lists, financial records, and lists of activities. Group dissolved in 1976.

Kanawha Woman's Club. Community Heritage Scrapbook, 1959. 1 vol.

Keokuk Presbyterial Society. Treasurer's records, 1887-1959. 7 vols.

King's Daughters and Sons, Electra Circle. Johnson County. Records, 1904 1971. $1 \mathrm{ft}$. Minutes, treasurer's reports, membership lists, and history.

La Coterie. Iowa City. Scrapbook, ca. 1932-1976. 1 vol. Records of book club, include photographs, constitution, programs, correspondence, and news clippings.

Ladies' Soldiers' Aid Society of Fort Dodge. Minutes and accounts, 1863-1865. $13 \mathrm{pp}$.

Lincoln Rural Women's Social Club. Lone Tree. Records, 1950-1976. 2 vols. Activities of club included luncheons, teas, tours, and learning crafts for home decoration.

Manville Heights Club. Iowa City. Secretary and treasurer's reports, 19191963. 7 folders.

Modern Mixers Club. Iowa City. Minutes, 1953-1983. 4 vols. Women's club formed by women employed as cooks in the University of Iowa fraternities and sororities or campus dormitories.

Monday Club. Iowa City. Secretary's books, 1920-1968. 6 folders.

Mt. Pleasant Woman's Club. Records, 1948-1983. 1 ft. Minutes, membership lists, treasurer's reports, scrapbooks, project books.

Music Study Club of Iowa City. Records, 1916-1977. 1 ft. Minutes, correspondence, news clippings. 
N.N. Club. Iowa City. Records, 1886-1995. 11/2 ft. Constitution and bylaws, minutes, program books, correspondence, history, photographs.

National League of American Pen Women. Iowa Branch. Records, 1932-1940. 1 folder. Includes correspondence of Waterloo branch, 1932-1940, and membership list for Iowa Branch, 1939.

Newburg Progress Club. Scrapbook of projects, 1955. 1 vol.

Nineteenth Century Club. Iowa City. Records, 1883-1972. $1 \mathrm{ft}$. History, minutes, programs, rules and regulations.

Orient Federated Woman's Club. Secretary's book, 1919-1924. 1 folder.

O.W.L. Club. Orient. History and minutes of meetings, 1907-1925. 1 folder.

P.E.O. Records, 1931-1978. $1 \mathrm{ft}$. Includes history of West Liberty and Farmington chapters, programs, poems, news clippings about the founders of P.E.O., and scrapbooks from Chicago chapter.

Perry Wednesday Study Club. Scrapbook of club projects, 1975. 7 folders.

Poetry Society of Iowa. Scrapbook, 1935-1944. 2 folders. Statewide organization. Minutes, news clippings, and members' poetry.

Pricilla Club. North Liberty. Club history, 1936, and photos of club members, 1914. 1 folder.

Pythian Sisters, White Rose Temple No. 111. Records, 1906-1996. 11/2 ft.

Richland Woman's Club. Speeches given at 30th (1932) and 60th (1963) anniversaries and history, 1974. 1 folder.

Royal Neighbors of America, Friendship Camp \#134. Bonaparte. Records, ca. 1899-1915. 1 vol. Organized as a social organization by women in Council Bluffs in 1888. Minutes, membership lists, and treasurer's reports.

Rundell Club. Iowa City. History, 1913-1963. 1 folder. History of neighborhood club reports on activities and history of streetcar route that opened area to working-class families.

Ruthven Women's Club. Scrapbook, 1956-1957. 1 vol.

Shakespearean Club. Osage. Scrapbook, 1959, and programs, 1916-1917 and 1938-1939. 1 vol.

Shakespeare Club of lowa City. Records, 1902-1982. $1 \mathrm{ft}$. Programs, constitution and bylaws, and secretary's books.

Sigourney First Presbyterian Church, Missionary Society. Secretary's handbook, 1903-1918. 1/2 ft.

Sioux City Diocesan Council of Catholic Women. History, 1919-1965. 4 pp.

Solon Study Club. Records, 1938-1994. $1 \mathrm{ft}$. Minutes, programs and directories, and pages from scrapbook.

Solon Teacher's Reading Circle. Secretary's books and notes on talks, 18941895. 2 vols.

Sorosis Club. Mt. Vernon. Secretary's books and roll books, 1896-1950. $1 \mathrm{ft}$. Includes history of the Woman's Improvement and Sorosis Clubs until they 
disbanded to become Mt. Vernon Woman's Club, 1895-1950. Also includes programs from Olin, Morning Sun, Sioux Rapids, and Riverton chapters.

State University of Iowa Equal Suffrage Association. Iowa City. Secretary's book, 1916-1917. 1 vol. Includes minutes, membership lists, officers, and constitution.

Theristriai Club. Marion. Scrapbook for 90th anniversary, 1957-1958. 1 vol.

Thursday Study Club. Albert City. History of club organized in 1917. 3 pp.

T.T.T. Iowa State Convention. Records, 1911-1975. $1 \mathrm{ft}$. Minutes, correspondence, speech, programs, state convention minutes, and local chapter records, such as two scrapbooks from Wellman.

Union Township Woman's Club, Johnson County. Records, 1921-1977. 1/2 ft. Secretary's books, annual reports, and history.

University Club. Iowa City. Records, 1917-1994. $11 \mathrm{ft}$. Club for women affiliated with the University of Iowa as faculty, staff, graduate students, alumnae, or faculty wives. Includes scrapbooks, annual reports, minutes, newsletters, and history.

University Dames. Iowa City. Correspondence, 1920-1921. 1 folder.

V.V. Club. Des Moines. Records, 1904-1968. 1/2 ft. Club formed by alumnae of Des Moines College, Highland Park College, and Des Moines University. Minutes, financial records, programs, and photos.

Washington County Hospital Nurses Alumnae Association. Records, 19211952. 3 folders. Minutes, constitutions and bylaws, and membership reports.

Wednesday Lookout Club. Secretary's book, 1896-1899. 1 folder.

Welsh Congregational Church of Old Man's Creek, Women's Home and Foreign Missionary Society. Records, 1891-1973. 1/2 ft. (9 vols.).

Westminister Study Club. Secretary's book, 1909-1916. 1 folder.

Whip-poorwill Club. North Liberty. History written for 50th anniversary, 1902-1952. 1 folder.

Woman's Christian Temperance Union. Records, 1937-1966. $1 \mathrm{ft}$. Includes records for Iowa City, Oelwein, and state of Iowa. Scrapbooks, minutes, news clippings, and convention programs. (Additional correspondence, pamphlets, and literature relating to Ellen Mather's WCTU activities in the Mather-Bush Papers).

Woman's Relief Corps. Henry Seibert Corps \#212. Wilton. Records, 1890-1930. $1 / 2 \mathrm{ft}$. Financial records and quarterly reports.

Woman's Relief Corps. Wm. McKinley Corps \#338. Kalona. Records, 19091962. $1 \mathrm{ft}$. Minutes, financial records, membership applications, and reports.

Women's Clubs of Johnson County. Scrapbook, 1952-1959. 1 vol. Includes programs, news clippings, bylaws and rules, certificates, individual club projects, and photos.

Young Women's Christian Association, Des Moines Area Council. Bulletin, May 24, 1933. 9 pp. Includes list of members, plans for a camp, and neighborhood conferences. 
Copyright of Annals of Iowa is the property of State of Iowa, by \& through the State Historical Society of Iowa and its content may not be copied or emailed to multiple sites or posted to a listserv without the copyright holder's express written permission. However, users may print, download, or email articles for individual use. 